\title{
VISUAL DISTURBANCES DURING TRANSURETHRAL RESECTION OF THE PROSTATE
}

\author{
Ray J. Defalque and Dennis W. Millek*
}

\section{CASE Report}

AN ALERT 72-year-old patient underwent a transurethral resection for prostatic adenoma. He was healthy except for mild pulmonary emphysema. The preoperative haemoglobin was $17.7 \mathrm{gm}$ per cent and the haematocrit 52.6. The serum electrolytes were $\mathrm{Na} \mathrm{142;} \mathrm{Cl} 103$ and $\mathrm{K} 5.6 \mathrm{mEq} / \mathrm{l}$. An EKG showed left axis deviation with frequent premature contractions.

He was given morphine 8 mgm intramuscularly 90 minutes before a hyperbaric spinal block with nupercaine $7.5 \mathrm{mg}$ which reached $\mathrm{T} 9$ sensory level. Diazepam $5 \mathrm{mg}$ injected intravenously at the beginning of the operation left him awake but quiet. Toward the end of the operation the initial BP of $120 / 80$ had fallen to $100 / 60$ but it returned to $140 / 80$ ten minutes after an intramuscular injection of ephedrine $50 \mathrm{mg}$. The operation was difficult and to avoid overhydration the patient received only $100 \mathrm{ml}$ of 5 per cent glucose in distilled water intravenously.

Twenty minutes after the beginning of the resection the patient complained of dizziness, epigastric palpitations, and "silver flecks before the eyes." Ten minutes later his vision had became blurred. After another five minutes he saw only shadows, and again five minutes later only a dim light. He was rational though anxious about his blindness. He had no dyspnoea and his chest was clear. The blood pressure remained $120 / 80$ throughout the episode.

The resection lasted 60 minutes. Blood loss was estimated at $900 \mathrm{ml}$. Glycine absorption was suspected. The prostatic chips weighed $23.5 \mathrm{gm}$. A traction catheter was inserted to control persistent prostatic bleeding. Seventy-five minutes after the beginning of the operation the patient entered the recovery room. He saw nothing except a faint glow. The serum electrolytes were then $\mathrm{Na} \mathrm{110,} \mathrm{Cl} 84$ and $\mathrm{K} 4.2$ $\mathrm{mEq} /$ lit. An ophthalmologist found normal fundi and pupillary reflexes, but absent eyelid reflexes. The EKG was unchanged. Thirty minutes after his admission to the recovery room the patient passed $200 \mathrm{ml}$ urine (sp.gr.1.001) and his eyesight improved. Urine volume was $2,000 \mathrm{ml}$ during the next two hours and normal vision slowly returned. He recovered completely.

\section{Discussion}

Significant quantities of irrigating solution may be absorbed into the circulation during transurethral resection of the prostate, leading to cerebral oedema "akin to water intoxication."1

Neurologists describe mental changes including apprehension, restlessness, con-

- Dept. of Anesthesiology, Indiana University Medical Center, Indianapolis, Indiana, U.S.A. 
fusion and convulsions after water intoxication, but no visual disturbances. ${ }^{2,3}$ Urologists have occasionally reported blurred vision ${ }^{1}$ or blindness ${ }^{4,5}$ associated with these mental changes, but have overlooked the mechanism causing them. Our patient's symptoms suggest cortical (occipital) blindness rather than oedema of a specific eye structure. ${ }^{6}$ The unchanged blood pressure during most of the episode, the normal retinal vessels and optic disc reported by the ophthalmologist and the return of vision after diuresis suggest cerebral oedema rather than ischaemia from hypotension, vasospasm, or increased intracranial pressure as the cause of blindness.

Ours seems the only reported case of visual disturbance without mental manifestations after transurethral prostatic resection. It leads us to speculate whether the visual symptoms are not an early sensitive sign of overhydration, preceding the mental changes and worth checking in conscious patients during prostatic resection.

\section{SUMmary}

We present a case of temporary blindness without mental changes following over-hydration during transurethral resection of the prostate. The symptoms suggest oedema of the occipital cortex.

\section{RÉSUMÉ}

Nous presentons un cas de perte de vision temporaire, sans autres symptomes cerebraux, a la suite d'absorption excessive de liquides durant une resection prostatique transurethrale. Sa symptomatologie nous fait soupconner un œedème du cortex occipital.

\section{REFERENCES}

1. Ceccarelli, E.E. \& Mantell, L.K. Studies of fluids and electrolytes alterations during transurethral prostatectomy. J. Urol. 85: 75-82 (1961).

2. Katzman, R. Effect of electrolyte disturbances on the central nervous system. Ann. Rev. Med. 17: 197-212 (1966).

3. Handbook of Physiology. Am. Physiol. Soc., Washington, D.C., 1960. Section I: Neurophysiology, vol. 3, pp 1761-1771 and 1865-1890.

4. BERG, G., FEDOR, E.J., \& Fisher, B. Physiologic observations related to the transurethral resection reaction. J. Urol. 87: 596-600 (1962).

5. Harrison, R.H., Boren, J.S., \& RoBison, J.R. Dilutional hyponatremic shock: another concept of the transurethral prostatic resection reaction. J. Urol. 75: 95-110 (1956).

6. Walsh, F.W. \& HoYt, W.F. Clinical neuro-ophthalmology. Third edition, Baltimore, Williams \& Wilkins, Vol. I, pp. 90-93 (1969). 